\title{
The Origins and Fate of James Currie's Cold Water Treatment for Fever
}

\author{
JOHN M FORRESTER*
}

There is now an established understanding that sweat, and perspiration in general, function as an important regulator of body temperature. This understanding has displaced the earlier view of humoral pathology, that sweating is a means of excreting excess or ill-mixed humours. Its role in regulating heat loss could not be clearly discerned until the measurement of heat loss by evaporation in the eighteenth century, particularly by William Cullen (1710-90) and his pupils. This paper's aim is to describe how understanding of heat loss from the human body developed, especially in the hands of James Currie (1756-1805), and how the growing understanding accompanied a novel and for some time popular approach to the treatment of fevers.

The function of sweating was understood in antiquity to be the excretion of surplus "wet" from the body, "wet" being one of the four "qualities" (warm, cold, dry, and wet) and not one of the four humours (black bile, yellow bile, phlegm and blood). ${ }^{1}$ During the long ascendancy of humoral pathology, the natural belief was that excesses of humours too could be unloaded in this way, as they could by the kidneys and the alimentary canal. So Galen refers to sweat as an excretion:

All such harmful matters that are of a finely particulate nature go out through the skin, some by insensible perspiration, and some visibly, as sweat does. Coarser matters cannot traverse the thickness of the skin, but are excreted by means of drugs or purges or enemas or by vomiting. $^{2}$

Thus he was aware of insensible perspiration, which either diffuses through the skin or is sweat from sweat glands that evaporates too quickly to be visible. But his main

* Dr John M Forrester, 120 Morningside Drive, Edinburgh EH10 5NS, Scotland.

I am much indebted to Dr John Henry of the Science Studies Unit, University of Edinburgh, for constructive comments on a draft of this paper, and to Professor Bynum and the anonymous referees of Medical History for invaluable criticism.

\footnotetext{
${ }^{1}$ The Hippocratic Aphorism VII.62 runs: "Continual sweating ... means that there is an excess of fluid [The Greek word is vipóv.] in the body." (John Chadwick and W N Mann, The medical works of Hippocrates, Oxford, Blackwell Scientific Publications, 1950, p. 176.) A discussion of the complex relation between "qualities" and
}

humours may be found in Thomas S Hall, Ideas of life and matter: studies in the history of general physiology $600 B C-1900 A D$, University of Chicago Press, 1969, pp. 140ff.

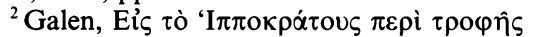
'Y $\pi$ ó $\mu \nu \eta \mu \alpha$, In Hippocratis librum de alimento commentarius III, sect.17, in Claudii Galeni Opera Omnia, 20 vols, ed. C G Kühn, Leipzig, C Cnobloch, 1821-1833, vol. 15, p. 323): 'A $A \lambda$ ' 'ó $\sigma \alpha$

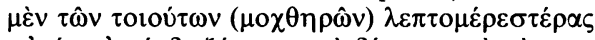

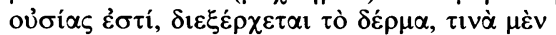

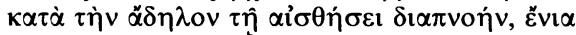

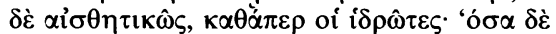

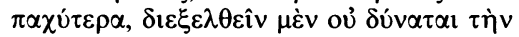

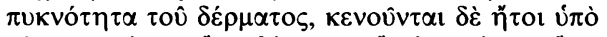

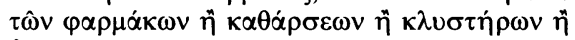
$\varepsilon \dot{\mu \varepsilon ́} \tau \omega \mathrm{v}$. 


\section{John M Forrester}

interest in sweat lay in how to provoke it by drugs, and in its use as a good or bad sign of the course of a disease.

This traditional view of sweat's function was not challenged when Sanctorius (1561-1636) measured insensible weight loss from the body, since he too viewed the function as excretory. Its role in heat loss was not clearly evident to him. But, noticing that in hot weather sweating made people feel better, he did have some insight into this aspect: "To those who have the Perspirable Matter obstructed in very hot Whether [sic], 'tis very troublesome: But to those who freely perspire their due Quantity, the Heat is not uneasy." ${ }^{3}$ Although he was an inventor of the thermometer, his was inadequate to indicate a fever except by the altered rate of change of its reading. ${ }^{4} \mathrm{He}$ did not investigate insensible weight loss in fever.

As a rule, fevered people got better as they sweated; they felt cooler; they seemed cooler to the observer's hand; the offending humours were leaving them in the sweat. Hence it was rational and customary in the terms of humoral pathology to encourage vigorous sweating during fever, and so to enclose the patient in heavy bedding, besides administering diaphoretic drugs such as Dover's Powder (ipecacuanha and opium) to promote gentle sweating, or even sudorific drugs such as antimony, to do it more potently. But Thomas Sydenham (1624-89) noticed that instead of relief, these measures produced discomfort or worse, and he denounced them as imprudent. Accepting that sweat might serve a useful function by carrying off some poisons, nevertheless he counselled against vigorously mobilizing such poisons for excretion; "they might inflame the remainder of the blood." Overheating he deplored; its opposite, vigorous cooling, would presumably reduce natural sweating and be also unwise; a judiciously cool regime was his advice. ${ }^{5}$ Boerhaave (1668-1738) concurred. ${ }^{6}$

The practical treatment of fever no longer required sweating. And sweating's true function as an important agent in stabilizing body temperature gradually became better understood. Fahrenheit (1724), ${ }^{7}$ and subsequently Martine (1738) recorded the stability, as soon as thermometric technique established proper scales. ${ }^{8}$ How

\footnotetext{
${ }^{3}$ See John Quincy, Medicina statica, being the aphorisms of Sanctorius, translated into English with large explanations, 2nd ed., London, $\mathrm{W}$ and J Newton [etc.], 1720, Sect 1, Aphorism 78. Quincy's "Explanation" of this Aphorism runs: "Because the obstructed Matter not only encreases the Weight, but also at such Seasons is apt to raise praeternatural Ferments, and occasion Putrefactions; or at least to contract such Qualities during its Stagnation, as may render it irritating and troublsome [sic]; all which Inconveniences are prevented, when the Perspirable Matter, as soon as made, flies off." Also note Sect 1, Aphorism 47: "Feverish Persons are as much in Danger, when Perspiration is hinder'd by an unskilful Administration of Medicines, as by their own Errors."

${ }^{4} \mathrm{~F}$ Sherwood Taylor ('The origin of the thermometer', Ann. Sci., 1942, 5: 129-56) pointed out (p. 139) that this would be effective, since during a fever there is at times a vigorous blood circulation to the skin, which feels hot and would
}

convey heat more rapidly than normal to the thermometer.

${ }^{5}$ Thomas Sydenham, Epistolae responsoriae duae a Thoma Sydenham, MD, prima de morbis epidemicis ab anno 1675 ad annum 1680. Ad Robertum Brady ... secunda de luis venereae historia et curatione. Ad ... Henricum Paman, 2nd ed., London, Walter Kettilby, 1685, p. 12.

${ }^{6}$ Hermann Boerhaave, 'Aphorismi de cognoscendis et curandis morbis', in Opera omnia medica, Venice, L Basilius, 1757, Aphorisms 690-99.

${ }^{7}$ D G Fahrenheit, 'Experimenta et observationes de congelatione aquae in vacuo facta', Phil. Trans. Roy. Soc. 1724, no. 381: 78-84.

${ }^{8}$ George Martine, Essays and observations on the construction and graduation of thermometers, and on the heating and cooling of bodies, 2nd ed., Edinburgh, Alexander Donaldson, 1772; this work is a set of four essays dated 1738-9. 


\section{James Currie's Cold Water Treatment for Fever}

could this stability be achieved? The animal heat (whatever its true origin) might perhaps be fanned or smothered. ${ }^{9}$ Martine thought that the internal friction in the circulation, which was at the time considered the source of the heat, would be greater in the pounding blood circulation of fever, thus accounting for the higher temperature. Alternatively, or as an additional means of control, the loss of heat from the body might be regulated. William Cullen in Edinburgh (1756) began the measurement of heat loss through evaporation, but the loss he studied was from a thermometer bulb, not from the living body; he was investigating a phenomenon of physics and he made no mention of sweating. ${ }^{10}$ Cullen's pupil and successor Joseph Black (in lectures from 1761 onwards) described his own discovery and measurement of the phenomena of "latent heat" (the phrase he coined) which underlie heat loss by sweating:

I am persuaded that the heat absorbed in spontaneous evaporation greatly contributes to enable animals to bear the heat of the tropical climates, where the thermometer [recording environmental temperature] frequently continues to shew the temperature of the human body. Such heats, indeed, are barely supportable, and enervate the animal, making it lazy and indolent ... The inhabitants are induced to drink large draughts of diluting liquors, which transude through their pores most copiously, carrying off with them a vast deal of this troublesome and exhausting heat ... The excessive perspiration, supplied by diluting draughts, performs the same office as the cold air without the tropics, in guarding us from this fatal accumulation."

Even to Black (1767) sweat seemed still an excretory channel for excess material, especially in fever, rather than a path for heat loss, as a student's notes of his lectures at that time record:

In Perspiration the Subtile Matter is thrown out, $w^{c}$ arrises from the Surface of our body \& Lungs, as we see in Cold or Damp Air; or a plate of Glass Condenses this Vapour, but $\mathrm{w}^{\mathrm{n}}$ we want to collect a $\mathrm{q}^{\text {ty }}$ of this Matter we can say but little of its Nature as its extremly Volatile so as not to be known, what its constituent part.-It contains oy ${ }^{r}$ Substances besides Water $w^{c}$ are probably oily and Volatilizd Matter;-In fevers $w^{n}$ this evacuation has been stopt \& restord again we find it have a very Strong Smell; so it seems to through [presumably "throw"] out of the body what would be hurtfull to us. ${ }^{12}$

\footnotetext{
${ }^{9}$ Everett Mendelsohn, Heat and life: the development of the theory of animal heat, Cambridge, Mass., Harvard University Press, 1964 , traces the discovery of the origin of animal heat.

${ }^{10}$ William Cullen, 'Of the cold produced by evaporating fluids, and of some other means of producing cold', Essays and observations physical and literary read before a society in Edinburgh, Edinburgh, Hamilton and Balfour, 1756, vol. 2, pp. 145-56.

"Joseph Black, Lectures on the elements of chemistry, ... now published from his manuscripts by John Robison, 2 vols, Edinburgh, Mundell \& Son, 1803, vol. 1, p. 214. Because Black's discoveries were published in printed form only posthumously, there is perennial difficulty in determining confidently when they were made. Douglas McKie and David Kennedy remark ('On some letters of Joseph Black and others', Ann.
}

Sci., 1960, 16: 129-70, p. 134.) that "It is clear that the historical value of the content of the printed Lectures is not very great, and that statements in that work are to be ascribed to Black only when they can be confirmed by independent evidence from other sources." See also A L Donovan, Philosophical chemistry in the Scottish Enlightenment, Edinburgh University Press, 1975, especially ch. 9: 'The theory of latent heat'; and Douglas McKie and Niels $\mathrm{H}$ de V Heathcote, The discovery of specific and latent heats, London, Edward Arnold, 1935.

${ }^{12}$ Thomas Cochrane, Notes from Doctor Black's lectures on chemistry 1767/8, ed. Douglas McKie, Cheshire, Imperial Chemical Industries, 1966, p. 187. There is nothing in these notes to indicate that in 1767 Black clearly perceived the cooling role of sweating, though evidently he did so some time later; see note 11 above. 


\section{John M Forrester}

Black's pupil James Hamilton (1771) stood on the watershed between the older and the newer understanding of sweating, listing the functions of sweating as (1) to correct excess of fluid, so that the equilibrium between solids and fluids is maintained; (2) to get rid of surplus food constituents; (3) to maintain the sensitivity of the skin; and (4) "Quaeritur, An perspiratione corpus refrigeretur?" A new hypothesis, evidently: that the body is cooled by perspiration. ${ }^{13}$ Charles Blagden investigated (1775) how far the stability of body temperature could be explained simply as fanning or smothering of the animal heat. Clearly this could not work when the environment was actually hotter than body temperature. Blagden took up a proposal of George Fordyce (1736-1802), a favourite pupil of Cullen at Edinburgh who had taken his doctorate there in 1758, and arranged an exceedingly hot room. During a first series of spells in the hot room, the body temperature of himself and his colleagues remained stable, and they wondered whether there might exist some "power capable of producing or destroying heat, just as the circumstances of the situation require."14 During a second series, with similarly stable body temperatures, Blagden noted that the onset of sweating gave instant relief, and concluded that evaporation is a "powerful assistant in keeping the living body properly cool ... but it can act only in a gross way." He surmised that the sweat might be measured, and regretted that he had no Sanctorian balance: "from the quantity lost some estimate might be formed of the share which the perspiration had in keeping the body cool; probably its effect was very considerable, but by no means sufficient to account for the whole of the cooling, and certainly not equable enough to keep the temperature of the body to such an exact pitch." Such an estimate required the power of Black's discoveries about latent heat, which were evidently not clearly transmitted to Blagden when he was Black's student at Edinburgh in $1765 .^{15}$

\section{Currie's Early Research}

James Currie showed evidence of what was to become a life-long close interest in body temperature and fever during the second year of his medical training at Edinburgh (1778-79). His concern has been attributed to episodes of fever he suffered during a stay in America during his teens. ${ }^{16}$ Much more significant is the already well-established attention paid to this theme within the Edinburgh medical school, led by Cullen and Black. By the time Currie arrived there, two doctoral theses and

\footnotetext{
${ }^{13}$ James Hamilton, Dissertatio medica inauguralis de perspiratione insensibili, Edinburgh, Balfour, Auld \& Smellie, 1771.

${ }^{14}$ Charles Blagden, 'Experiments and observations in a heated room', Phil. Trans. Roy. Soc., 1775, 65: 111-23. 'Further experiments and observations in a heated room', ibid.: 484-94; at page 122 .

${ }^{15}$ Blagden's autograph notes of Black's lectures on heat survive (Western MS 1219 in Wellcome Library, London); they include no
}

quantitative data on assessment of latent heat; either Black had not then acquired them, or he did not cover them in the lectures Blagden attended. I am indebted to Professor Bynum for pointing to this source. See note 11 above on Black's failure to publish.

${ }^{16}$ William Wallace Currie (ed.), Memoir of the life, writings and correspondence of James Currie, $M D, F R S$, of Liverpool, 2 vols, London, for Longman [etc.], 1831, vol. 1, p. 11. 
a student dissertation had recently appeared devoted to themes of heat, latent heat and animal heat. ${ }^{17}$

The earliest evidence of Currie's interest consisted in an address he delivered while a medical student to the Royal Medical Society of Edinburgh during the session 1778-79 entitled 'What are the effects of cold on the living body?'. His autograph script survives. ${ }^{18}$ Its contents display the dependence on the views of his instructors, especially Cullen, that one would expect at this stage of his career. He expresses an explicit recognition of the "higher and lower degrees of the great scale of Temperature which come under the observation of the Senses", and asserts that the "human heat is between $97^{\circ}$ and $98^{\circ}$ of Fahrenheit". He sees the effects of cold upon the human body as both stimulant and sedative. He has grasped the link between evaporation and cooling, but has certainly nothing yet to say about sweat nor about the use of cold water in fever, which came to concern him closely later in his career. ${ }^{19}$

Once qualified in medicine, Currie established himself as a physician in Liverpool (1781), and an event nearby in 1790 rekindled his interest in the effects of cold: a shipwreck, in which, surprisingly, eleven of the crew largely immersed in sea water for hours survived, but the ship's master and a passenger, who were out of the water but exposed to wind and sleet, both died. Currie's account (1792) relates that he was at first inclined to attribute the contrast to some differing effect of fresh and salt water, but later was guided by his own experiments on human subjects to suspect that heat loss through evaporation in the wind was responsible for the deaths of the victims who were not immersed, which is what would be believed nowadays. ${ }^{20}$

Currie set out to investigate the practical problems of shipwreck and how to deal with them. In contrast to Blagden and his colleagues, who had used hot environments to attack basic rather than practical problems, Currie's method was to replicate exposures to cold similar to those undergone by the victims. ${ }^{21}$ Having questioned

\footnotetext{
${ }^{17}$ James M'Clurg [sic], Tentamen medicum inaugurale de Calore, Edinburgh, Balfour, Auld \& Smellie, 1770; Nat. Tucker, Is the doctrine of latent heat well founded?, Royal Medical Society Dissertations held in Edinburgh University Library, vol. 5 (1772), p. 193ff; P Dugud Leslie, Philosophical enquiries into the cause of animal heat, London, S Crowder, et al., 1778. (The substance of this was an inaugural thesis at Edinburgh in 1775.)

${ }^{18}$ James Currie, 'Dissertation read before the Royal Medical Society of Edinburgh during the session 1778-1779', held in microfilm $F / N$ 96935/3 at Edinburgh University Library, vol. 11, pp. 288-300. R D Thornton (James Currie, the entire stranger, and Robert Burns, Edinburgh and London, Oliver \& Boyd, 1963, p. 81) wrote that this was one of two papers that Currie gave to the RMS and that "neither is known to exist", but this one does and the other never did; the tale of two papers began with W W Currie, op. cit., note 16 above, and is not confirmed by the Index of RMS papers.
}

\footnotetext{
${ }^{19}$ Cullen's teaching is evident here; what Currie had gathered from Black is less clear, since Currie only mentions Black's famous phrase "latent heat" once (p. 295), and then only in relation to how vegetables might survive in very hot climates.

${ }^{20}$ W R Keatinge, Survival in cold water, Oxford and Edinburgh, Blackwell Scientific Publications, 1969, gives a modern account, and (p. 2) recognizes Currie's priority in clearly identifying that cold was the killer in shipwreck as a rule.

${ }^{21}$ Currie's paper made no reference to Blagden's 1775 papers, and no private communication between the two men is present in the Blagden archive at the Royal Society. I am indebted to Mary Sampson, Archivist to the Royal Society, for this information. But Currie certainly referred to Blagden's work later, and was a friend of Dr Park, who had been a subject in Liverpool replications of the hot room experiments (Matthew Dobson, 'Experiments in a heated room', Phil. Trans. Roy. Soc., 1775, no. 65: 463-9).
} 


\section{John M Forrester}

the survivors, and estimated the likely air and sea temperatures at the time of the shipwreck, Currie followed the body temperature changes found in naked human subjects during exposure to cold salt water in a large tank in the open air, and also when wet in the air after removal from the tank, and during recovery in a warm bed. One subject's mouth temperature fell to $88^{\circ} \mathrm{F}\left(31^{\circ} \mathrm{C}\right)$, and more than one felt extremely ill. Currie used himself as subject on one or two occasions, but treated himself more gently. He was puzzled by findings that he could not explain, but which are soluble in modern times: for instance, that a markedly chilled person taken out of cold water into warmth shows at first a further fall in body temperature. (This is because the reopening blood circulation starts perfusing chilled subcutaneous tissue and losing body heat into it.) Currie thus acquired a first-hand familiarity with the measured effects of exposure to cold water on body temperature, and he monitored the course of recovery in various circumstances. ${ }^{22} \mathrm{He}$ also gained then and subsequently an excellent grasp of practical thermometry applied to the human body.

\section{Clinical Thermometry and its Interpretation}

Environmental temperatures were, of course, by this time easy to take, ${ }^{23}$ and a widely-travelled physician such as Robert Robertson in 1807 recorded large numbers of them, but no body temperatures. ${ }^{24}$ Clinical thermometry and its interpretation were attended by particular problems, but there was nothing entirely new at this time in thermometry being applied to the human body. ${ }^{25}$ Properly calibrated instruments had been used to record body temperatures at least forty years earlier by George Martine, ${ }^{26}$ and the body temperatures of feverish soldiers were being recorded in the Netherlands in $1748 .^{27}$

Currie specified the instruments he used, and the procedure for obtaining a valid reading:

I have generally used a small mercurial thermometer of great sensibility, with a moveable scale, made for me by Mr Ramsden, after a form invented by the late Mr Hunter [John Hunter (1728-93)], and used by him in his experiments on the heat of animals, and I have

\footnotetext{
${ }^{22}$ James Currie, 'An account of the remarkable effects of a shipwreck on the mariners; with experiments and observations on the influence of immersion in fresh and salt water, hot and cold, on the powers of the living body', Phil. Trans. Roy. Soc., 1792, pt 2: 199-224.

${ }^{23} \mathrm{~W}$ E Knowles Middleton, $A$ history of the thermometer and its use in meteorology, Baltimore, Johns Hopkins Press, 1966.

${ }^{24}$ Observations on fevers which arise from marsh miasmata and from other causes, in Europe, Africa, the West Indies, and Newfoundland, with occasional remarks on the principal diseases incident to seamen, 4 vols, London, for T Cadell etc., 1807.

${ }^{25}$ The early technical difficulties are described by Stanley Joel Reiser, Medicine and the reign of technology, Cambridge University Press, 1978, pp.
}

110-14; he writes, however, of James Currie "who tried to predict the course of certain diseases by following the alterations in temperature", of which I find no evidence in Currie's writings.

${ }^{26}$ George Martine, De similibus animalibus et animalium calore libri duo, London, A Millar, 1740 , p. 173. Further details are provided in Martine, op. cit., note 8 above. His work was known to van Swieten in Vienna, who used adequate thermometers about the same time: see Gerard van Swieten, Commentaria in Hermanni Boerhaave aphorismos de cognoscendis et curandis morbis, 2nd ed., Leyden, Verbeek, vol. 2, 1749, p. 317.

${ }^{27}$ Francis Home, Dissertatio medica inauguralis de febre remittente, MD thesis, Edinburgh, Ruddimann, 1750, p. 15. 


\section{James Currie's Cold Water Treatment for Fever}

introduced the bulb under the tongue with the lips close, or under the axilla indifferently; having found by repeated experiments, that the heat in these two places corresponds exactly, and gives a just indication of the heat of the surface of the body where sheltered ... Finding, however, considerable risque [sic] in using the straight tubed thermometer in contagious diseases, I got some instruments of this kind made with a small bulb curved at the end. The bulb being introduced under the tongue or the axilla, the observer can stand behind the patient, and mark the rise of the mercury, without coming into the immediate sphere of his respiration. ${ }^{28}$

The risk of transmission of disease was taken seriously: Francis Home (1719-1813), Professor of Materia Medica at Edinburgh, advised students to "take only a side view of mouth and throat, supplementing this preventive measure with frequent rinsings of his own mouth in a solution of vinegar and water."29

A contemporary clinical thermometer made in Edinburgh is in the Mütter Museum in the College of Physicians of Philadelphia. ${ }^{30}$ Like all clinical thermometers for the next eighty or so years, these were slow to respond, and had to be read while in position in the mouth or elsewhere, since the mercury column began to shrink as soon as they were removed into any cooler environment. ${ }^{31}$ It is of interest that even in Currie's time an attempt to overcome this problem was made by a $\mathrm{Mr} \mathrm{Six}$, who put a small piece of iron into a thermometer tube to convert it into a "maximum thermometer" and avoid the need for the observer to get very close to the patient, but apparently no lasting success was attained. ${ }^{32}$ The slowness of response meant that a reading might require seven minutes or even longer to achieve. Some workers, finding the time to reach a final reading impractically long, resorted to noting the rate of rise rather than the final reading, or to adding a supplement to the reading reached at a specified time. Anton de Haen, for instance, added two degrees at 7.5 minutes. ${ }^{33}$

Thus Currie's only reliable way of following the course of the decline in body temperature during exposure to cold was to watch the mercury column as it fell within the thermometer in the mouth of his normal subjects. Noting how rapidly it fell when some subjects were removed from the cold water and exposed to the air, he acquired a grasp of the significance of evaporation from the skin surface at low environmental temperatures, comparable to that reached by Blagden and his colleagues at high temperatures. He later on (1805) came to preach the function of

\footnotetext{
${ }^{28}$ James Currie, Medical reports on the effects of water, cold and warm, as a remedy in fever, and febrile diseases; whether applied to the surface of the body, or used as a drink: with observations on the nature of fever; and on the effects of opium, alcohol, and inanition, Liverpool, for Cadell and Davies, London, 1797, p. 33.

${ }^{29}$ Guenter B Risse, Hospital life in Enlightenment Scotland: care and teaching at the Royal Infirmary of Edinburgh, Cambridge University Press, 1986, p. 259.

${ }^{30} \mathrm{~J}$ Worth Estes, 'Quantitative observations of fever and its treatment before the advent of short clinical thermometers', Med. Hist., 1991, 35: 189-216; the instrument is described on p. 197.
}

${ }^{31}$ In 1864 William Aitken invented the selfregistering thermometer, which maintained its reading until the mercury column was shaken down. See Estes, ibid., p. 209.

${ }^{32}$ James Currie, Medical reports on the effects of water, cold and warm, as a remedy in fever and other diseases, whether applied to the surface of the body, or used internally, 4th ed., 2 vols, London, for T Cadell and W Davies, 1805, vol. 1, p. 36, and J Six, 'Account of an improved thermometer', Phil. Trans. Roy. Soc., 1782, 72: 72-81.

${ }^{33}$ Anton de Haen, Ratio medendi in nosocomio practico vindobonensi, 4 vols, Leyden, "sumptibus societatis", 1761, vol. 2 (published by $P$ van der Eyk in 1764), p. 321. 


\section{John M Forrester}

perspiration with missionary zeal: "a true theory of the principal function of the perspiration, that of regulating the temperature of the body in health and disease; a most important function, previously disregarded in the writings of our physicians on fever, and wholly overlooked in the works of what are called the systematic authors in medicine, not excepting the latest of them, Cullen, Brown, and Darwin [Erasmus]." ${ }^{34}$ Earlier practice had been to heat the fevered patient and make him or her sweat out the cause of the disorder: Currie had a new understanding of what sweat was for.

\section{Currie's Promotion of Vigorous Cold Water Treatment for Fever}

In the first edition of his Medical reports (1797) he enthusiastically advocated cold water for fever; he maintained then and later that he did so because it worked, and that he was prompted by the experience of Dr William Wright (1735-1819), who had in 1777 caught fever from a sailor on a boat near Jamaica, and had himself treated to his great satisfaction with cold water. He had noted the familiar value of cold drinks and cool air during fever, and went much further.

September 9th, having given the necessary directions, about three o'clock in the afternoon I stripped off all my cloaths, and threw a sea cloak loosely about me till I got upon deck, when the cloak also was laid aside: three buckets full of cold salt water were then thrown at once on me; the shock was great, but I felt immediate relief. The head-ach [sic] and other pains instantly abated, and a fine glow and diaphoresis succeeded. Towards evening, however, the febrile symptoms threatened a return, and I had recourse again to the same method, as before, with the same good effect. I now took food with an appetite, and, for the first time, had a sound night's rest. ${ }^{35}$

He went on with the cold affusions, as they were often termed, twice a day for a further two days, to ensure no relapse. Currie always scrupulously acknowledged his debt to Wright, and when carrying out his shipwreck experiments (1792) had tried out the same sort of vigorous cold douche once on one of his subjects. The pulse slowed, the subject was cooled; the prospects for useful treatment of fever seemed good; and Currie wrote: "Of this salutary practice I hope soon to speak at large to the public." "36 Wright, however, had recorded no temperature measurements nor clarified when cold water would help and when it would harm.

Unorthodox though it had been, this treatment was not entirely unprecedented. Cold water was a time-honoured expedient, deep-rooted in popular culture, to deal with very diverse disorders, or in the interest of general well-being. ${ }^{37}$ Floyer, for

\footnotetext{
${ }^{34}$ James Currie, op. cit., note 32 above, vol. 2, pp. 238-9.

${ }^{35}$ William Wright, 'Remarks on malignant fevers; and their cure by cold water and fresh air', Lond. med. J., 1786, 7: 109-15.

${ }^{36}$ James Currie, op. cit., note 22 above, p. 218.
} 


\section{James Currie's Cold Water Treatment for Fever}

example, had described its uses earlier in the century. ${ }^{38}$ But, for fever, cold bathing had been exceptional and unorthodox, though not entirely unknown. For example, Vespucci reported it among natives in America in the early sixteenth century, ${ }^{39}$ and in 1737 during an epidemic of fever at Bratislava washings with flowing cold water were tried in desperation, and described in dramatic language, picturing the element water battling with the element fire. ${ }^{40}$

\section{Detail of Currie's Treatment}

Currie advocated attention to measurement of body temperature, and he introduced an invaluable intuition for the correct moment to choose for vigorous cooling. $\mathrm{He}$ was no slave to the thermometer nor to any theory of fever which dictated that whenever the temperature was raised it should be brought down by any means available; ${ }^{41}$ instead, he limited the use of cold water treatment to occasions when the temperature was high but was likely soon to decline in the normal course of a recurring fever. He set out to anticipate the natural course of the fever rather than to oppose it, and his criteria of success included the patient's immediate relief as

\footnotetext{
${ }^{38}$ Sir John Floyer, The ancient $\psi v \times \rho o \lambda o v \sigma l \alpha$ revived: or an essay to prove cold bathing both safe and useful, London, S Smith and B Walford, 1702. Cold bathing was to Floyer one component of a wide-ranging "cold regimen" which was a Spartan armour against humoral disorders (including vices) rather than a weapon to attack fever. I am much indebted to Professor John Gabbay for access to his unpublished 1982 paper upon the bases of Floyer's thinking.

${ }^{39}$ Amerigo Vespucci, The first four voyages of Amerigo Vespucci reprinted in facsimile and translated from the rare original edition (Florence, 1505-6), London, Bernard Quaritch, 1893, p. 12: "They use in their sicknesses various forms of medicines, so different from ours that we marvelled how any one escaped: for many times I saw that with a man sick of the fever, when it heightened upon him, they bathed him from head to foot with a large quantity of cold water: then they lit a great fire around him, making him turn and turn again every two hours, until they tired him and left him to sleep, and many were [thus] cured." This is perhaps on the northern coast of Honduras, judging from the navigational details, according to the translator.

${ }^{40} \mathrm{John}$ Gottfried de Hahn, 'Epidemia verna quae Vratislaviam anno MDCCXXXVII gravissime afflixit descripta', Acta physico-medica
}

Academiae Caesareae Leopoldino-Carolinae naturae curiosorum exhibentia ephemerides, Nuremberg, Endteri consortium [etc.], 1754, vol. 10, Appendix. In this account of an epidemic at Bratislava (now in Slovakia) in 1737, de Hahn (not Anton de Haen (1704-76)) describes (p. 12) how in desperation, upon his old father's advice, he abandoned conventional treatment and washed his patients down with cold water, to destroy the "destructive sacred fires" of the fever: "His rerum angustiis, et consilio patris senis excitatus, ignis elemento destructori, inusitata methodo, opponere decernebam infestum ignibus elementum aquae, iugi ["running, flowing"] abluitione [sic] frigida vel praevertere, vel delere tentans ignes sacros, tot florentibus et vegetis corporibus ruinosos." He subsequently treated himself similarly, and survived. But he recorded no temperatures, and if he used any discretion about when to chill and when not, he does not mention it.

${ }^{41}$ Currie's vociferous rival Robert Jackson (1750-1827) misrepresented his method exactly thus (Robert Jackson, An exposition of the practice of affusing cold water on the surface of the body as a remedy for the cure of fever, to which are added, remarks on the effects of cold drink, and of gestation in the open air in certain conditions of that disease, Edinburgh, W Martin [etc.], 1808, p. viii). 


\section{John M Forrester}

well as reduced temperature and ultimate "cure". ${ }^{42}$ Currie's detailed instructions were often ignored later.

He fiequently recorded body temperatures before and after treatment. But he did not pursue the theoretically attractive course of lowering a raised body temperature by vigorous cooling, and monitoring the temperature until it reached a normal value. Monitoring of this kind had been a notable feature of his earlier observations on healthy men submerged in cold water or cooling in a breeze afterwards. There are several reasons which made monitored depression of body temperature during a fever inappropriate. First, he would have had to be in personal attendance continuously in order to read the thermometer, which required at that time much more competence than was commonly to be found at a bedside. The second reason for avoiding obsessive cooling of any patient showing a raised body temperature is the distress and harm caused to the patient, which were perfectly evident to Currie, and can nowadays be interpreted in the light of the "set point" understanding of body temperature: during fever the "set point" is raised above the normal level, and this higher temperature is reached and then vigorously maintained by shivering and similar exhausting responses in the face of any attempt to reduce it-except, presumably, when the "set point" is actually falling during the natural course of the fever. Lastly, he did not see the aim of treatment in such simple terms. Fever was not understood at the time as an elevated body temperature and nothing else; it comprised a more general disorder, involving in particular a "spasm" of the blood vessels, apparent in the pallor and coldness of the skin as the temperature rose, and resolved in the subsequent redness and heat as the temperature fell. In his own words, "The sudden, general, and powerful stimulus given to the system [by the cold water], dissolves the spasm on the extreme vessels of the surface, and of the various cavities of the body: the sudden and general evaporation carries off a large portion of the morbid heat accumulated under the skin; and the healthy action of the capillaries and exhalents [sic] being restored, the remaining superfluous heat passes off by sensible and insensible perspiration." ${ }^{43}$ This accords with William Cullen's

\footnotetext{
${ }^{42}$ See, for instance, op. cit., note 28 above, pp 15-16: "The safest and most advantageous time for using the aspersion or affusion of cold water, is when the exacerbation is at its height, or immediately after its declination is begun; and this has led me almost always to direct it to be employed from six to nine o'clock in the evening; but it may be safely used at any time of the day, when there is no sense of chilliness present, when the heat of the surface is steadily above what is natural, and when there is no general or profuse perspiration.- These particulars are of the utmost importance." Page 16: during the cold stage of a fever cold water "would extinguish life. This remedy should therefore never be used when any considerable sense of chilliness is present, even though the thermometer, applied to the trunk of the body, should indicate a degree of heat greater than usual." Nor if the thermometer temperature
}

is "only equal to the natural heat, though the patient should feel no degree of chilliness." Nor during profuse perspiration. Page 17:

"Perspiration is always a cooling process in itself, but in bed it is often prolonged by artificial means, and the body is prevented from cooling under it to the natural degree, by the load of heated clothes. When the heat has been thus artificially kept up, a practitioner, judging by the information of his thermometer only, may be led into error." Page 40: "In recommending the affusion of cold water as a remedy in fever, an express exception is therefore made against its use during the feverish chill, or after the perspiration has begun to flow profusely, and more especially after it has continued to flow profusely for some time."

${ }^{43}$ James Currie, op. cit., note 28 above, pp. 161-2. 


\section{James Currie's Cold Water Treatment for Fever}

teaching. ${ }^{44}$ The spasm was understood as extending not just to the circulatory system but also to the nervous system, where it led to shivering, cardiac palpitations, and restlessness. $^{45}$

\section{Early Enthusiasm}

The early applications of the treatment were to tropical and shipboard fevers, notably in the West Indies and in Liverpool, linked as they were at the time by a vigorous marine trade. The publicity secured for his treatment was widespread and rapid. As his son and biographer remarked, the impact of his book was improved by the "almost entire absence of those technical expressions, by which medical works are generally rendered unintelligible to all but members of the profession." ${ }^{46}$ By the time of the fourth edition of his work (1805; it was posthumous) a whole additional volume had to be provided to include the further experience of himself and of numerous correspondents, facing scarlatina, smallpox, measles, influenza, as well as shipboard fevers and tropical fevers. Particularly notable was the enthusiasm with which doctors treated their own children (as well as themselves). Currie treated his for scarlatina in 1801.

I shut myself up with these boys [two of his own]; and with plenty of pump water and a pocket thermometer, prepared, not without anxiety, to combat this formidable disease. ... As soon as the sensation of heat was steady in my eldest boy, I stripped him naked, and poured four gallons of water over him, of the temperature of $64^{\circ}$. The usual good effects immediately appeared, but at the end of two hours he was as hot as ever-the remedy was again applied, and repeated as the return of heat indicated. By the time the eldest was ready for his third affusion, the youngest was ready for his first. The heat rose in the eldest to $109^{\circ}$, in the youngest to $108^{\circ}$, and the pulse in each was upwards of 150 . In thirty-two hours the first had the affusion fourteen times; eight times cold, twice cool, and four times tepid. Twelve affusions sufficed in the case of the youngest, of which seven were cold. The fever was in both completely subdued. On the morning of the third day they were both evidently safe; $\ldots{ }^{47}$

It is evident that the full force of cold affusion was used at the outset of the disease, and tended to be replaced by cool and then by tepid affusion. His Edinburgh colleague James Gregory was equally vigorous (and successful) in 1803. Another later report records the case of a child in the fourth day of croup, pulse barely perceptible, eyes sunken, Hippocratic face. His doctor father, in despair, tried the cold affusion. The sick child was so much relieved that the father repeated the treatment with each exacerbation, ten times in all, and recovery occurred. ${ }^{48}$

\footnotetext{
${ }^{44}$ See for instance 'Of fevers' in his textbook first published in 1777, 'First lines of the practice of physic' (in his Works, ed. John Thomson, 2 vols, Edinburgh, William Blackwood, 1827, vol. 1, pp. 493-4). Cullen credited this account of the disorder chiefly to Friedrich Hoffmann (1660-1742).

${ }^{45}$ Estes, op. cit., note 30 above, p. 192. See also W F Bynum, 'Cullen and the study of fevers in Britain, 1760-1820', in W F Bynum and V Nutton (eds), Theories of fever from antiquity to
}

the enlightenment, Medical History, Supplement No. 1, London, Wellcome Institute for the History of Medicine, 1981, p. 138.

${ }^{46} \mathrm{~W}$ W Currie, op. cit., note 16 above, vol. 1, p. 214 .

${ }^{47}$ James Currie, op. cit., note 32 above, vol. 2, pp. 54-5.

${ }^{48}$ The report is in the Journal der practischen Arzneykunde und Wundarzneykunst (Hufeland und Osann), 1825, 60: pt 5, 75-101. The doctor was David Harder (1769-1833). 


\section{John M Forrester}

In later years it was customary for those who knew about thermometry to make respectful reference to Currie, but lament that his work failed to achieve the influence it deserved. For example, Wunderlich (1871) wrote:

Towards the conclusion of the last century (1797) there appeared a work which was singularly free from mere theories, and in the highest sense of the term, practical. For the first time since the observations of de Haen, temperature observations were made available for medicinal purposes, especially for the therapeutic indications they afforded, and as a means for controlling therapeutic experiments. This was James Currie's 'Medical reports on the effect of water, cold and warm, as a remedy in fever and other diseases.' ... Although Currie's work ran through several editions in England, and was very favorably reviewed, yet it influenced his contemporaries and countrymen but little. Its influence on Germany was still slighter. ${ }^{49}$

Such assessments of Currie's failure to get thermometry introduced into the practice of clinical medicine were fair enough. In the United States, for instance, the thermometer was still not in general use in $1866 .^{50}$

But his cold water treatment fared better, for several decades. A London physician wrote in 1818 that Currie's labours "deserve to be consecrated by a national monument." ${ }^{\prime}$ It is not surprising that his message about cold water was being relayed with fidelity at the Edinburgh medical school which had trained him, in theses for the doctorate in medicine up to $1823 .{ }^{52}$ But whatever might be written about it, it appears that cold water was administered there with some circumspection, at least after some experience of it. Two student casebooks survive from 1808-9 and describe the handling of about 28 febrile patients and 37 non-febrile. Of the febrile patients, only three were treated by cold affusion, and four by tepid affusion. ${ }^{53}$ The reservations of the medical staff are clearly spelt out.

His treatment was taken seriously in Germany. Medical reports was translated and published at Leipzig in 1801. Twenty years later, Hufeland took a major step in promoting assessment of Currie's work on cold water treatment, by announcing a fifty ducat prize for the best essay on it; essays had to review the work critically, include the author's own observations on thermometry, and provide interpretation.

\footnotetext{
${ }^{49} \mathrm{C}$ A Wunderlich, On the temperature in diseases: a manual of medical thermometry, transl. W Bathurst Woodman, London, New Sydenham Society, 1871 (1st German ed. 1868), pp. 24-5. T Clifford Allbutt ('Medical thermometry', Br. For. Med.-Chir. Rev., 1870, 45: 429-41 and 46: 144-56) remarked that the time was not ripe for Currie and his predecessors until "the more general laws of heat were known".

${ }^{50}$ Edward C Seguin, 'The use of the thermometer in clinical medicine', reprinted from Chicago Medical Journal of May 1866 in Seguin's Opera minora, New York, G P Putnam's Sons, 1884, pp. 1-9. The likely reasons for its neglect are discussed by Estes, op. cit., note 30 above, pp. 214-15.

${ }^{51}$ John Armstrong, Practical illustrations of the scarlet fever, measles, and pulmonary
}

consumption, with observations on the efficacy of sulphureous waters in chronic complaints, 2nd ed., London, for Baldwin, Cradock, and Joy, 1818, p. 41 .

${ }^{52}$ Thomas Nelson, De frigoris effectibus in morbis medendis, Edinburgh, Adam Neill [etc.], 1799; Thomas Stewart Traill, Dissertatio medica inauguralis de usu aquae frigidae in typho, externo, Edinburgh, Alex. Smellie, 1802; Robert Lorimer, De frigoris effectibus in corpus humanum, quum sanum, tum morbidum, Edinburgh, John Moir, 1823. Traill also did a little experimentation on himself in health, repeating some of Currie's work on exposure to cold water.

${ }^{53}$ Lothian Health Board Archive 1/125/3 and $1 / 125 / 4$ in the Special Collections of the University of Edinburgh's Library. 


\section{James Currie's Cold Water Treatment for Fever}

He published the best essay and two others in 1822; all had the same title. ${ }^{54}$ But he was not impressed in the long run, like many others, probably for the reasons to be discussed later; his Encheiridion medicum oder anleitung zur medizinischen praxis ${ }^{55}$ does not go beyond commending cool air and bedding for febrile patients, and does not mention thermometry at all.

The three prize essays exhibit a thorough acquaintance with the earlier history of the subject, and with the details of Currie's advice. The first two include numerous observations of temperature, pulse rate and general condition as affected by treatment with cold water. The patients were often children, with scarlatina or measles. The prizewinner (Anton Frölich (1760-1846) of Vienna) lost no patient whom he thus treated. His experience of immersing patients in baths at various temperatures led him, as it led others, to modify significantly Currie's heroic exposures to douches of very cold water, which he learnt to reserve for very high fevers; he came in general to use washing with water rather than immersion or douche, and drew up a table relating the patient's temperature to the temperature of water to be used for washing him or her. Thus a patient with a slight fever would be washed with water as warm as $85^{\circ} \mathrm{F}$, and one with a temperature of $106^{\circ}$ with water at $40^{\circ} \mathrm{F}$.

The third essay differs from the others in being the work of a country doctor, who explained that he could not use thermometry nor provide frequent observations, because he was treating people at home, who would not as a rule tolerate heroic exposures to cold water. He used cold washing, and pouring cold water over the head, following the general principles of Currie, which had never required thermometer readings as a necessity. ${ }^{56}$

Central European enthusiasm still persisting in 1831 is reflected in a MD thesis from Prague. ${ }^{57}$ The author is scrupulous in paying tribute to Currie (and to Wright), and sets out in lengthy detail all the ways in which the cold water could possibly be applied-even by slow dripping onto the top of the shaven head. The most favoured procedure seemed to be to sit the patient upright in a bath part filled with warm water, and then pour cold water onto him from a height of two or three feet or more. The author attributes to Currie a remarkable device enabling a wooden water bucket ("vas ligneum") to be tipped up over the invalid by pulling a rope. The gooseflesh and the gasping are clearly described, and some element of "terror" is evidently regarded as an advantage..$^{58}$ As Estes remarks about the therapies of the time, "all the weapons in the physician's normal armamentarium worked"-in the

\footnotetext{
54 ‘Abhandlung über die äusserliche Anwendung des kalten Wassers zur Mässigung des Fiebers, und über die Anwendung des kalten Wassers als Arzneymittel überhaupt', Journal der practischen Heilkunde (Hufeland),

Supplementstück des Jahrgangs 1822, Berlin, Reimer.

${ }^{55}$ Berlin, Jonas Verbuchhandlung, 1836.

${ }^{56} \mathrm{~J}$ A Pitschaft (1783-1848) in op. cit., note 54 above, pp. 123-99.

${ }^{57}$ Albertus Kraus, De frigoris externi in
}

curandis morbis acutis febrilibus praestantia in genere, et de methodo perfrigerante Doctorum Wright et Currie in specie, Prague, Joannes Spurny, 1831.

58 "Est remedium forte, heroicum sed tanto efficacior"-Heinrich Bluhme, Morborum curationes per frigus, Göttingen, Litteris Barmeierianis, 1773 , p. 2. This thesis, published before Currie's work, discusses cold water treatment for a long and diverse catalogue of ailments. 
sense of doing something manifest which did not preclude natural recovery. ${ }^{59}$ Afterwards, the patient is scrubbed well, dried, and put to bed in warm bedding, with a woolly nightcap to keep the shaven scalp warm. Cautious treatment at first is recommended, and "the use of the thermometer should never be overlooked". The temperature of the water could be selected according to Frölich's table already mentioned, which moderated Currie's original all-or-none approach by recommending that the milder fevers should be treated with warmer water, and vice versa.

Across the Atlantic, enthusiasm for cold bathing seems even to have preceded the publication of Medical reports in 1797. Benjamin Rush, himself a graduate of Edinburgh's medical school where he had studied from $1766-68,{ }^{60}$ noted widespread and "indiscriminate" prescription of cold bathing by physicians at the outset of the 1793 episode of yellow fever at Philadelphia. In the same year, a contributor to the Gazette of the United States remarked: "Be patient ye vivid sons of mercury with the medical baptisms of your cold bath brethren [his italics]. For had that therapeutic process been tried under the cataract of Niagara, no body can tell the wonders which might have been produced by it." ${ }^{\prime 1}$ Rush did not then approve of this treatment, unless prophylactically to preserve health, and had earlier described its use by American Indians for smallpox: "We are told that they plunge themselves in cold water in the beginning of the disorder, and that it generally proves fatal to them." ${ }^{\prime 62}$ And so he recorded with relief that Philadelphia's physicians soon turned back to more traditional expedients: "Not less than 6,000 of the inhabitants of Philadelphia probably owe their lives to purging and bleeding, during the autumn."

However, when Currie's Medical reports appeared four years later, Rush took proper notice of the contraindications so carefully set out by Currie, and even claimed some credit: "It has lately given me great pleasure to find the same practice ... recommended by Dr Currie of Liverpool, in his medical reports of the effects of water, cold and warm, as a remedy in febrile diseases." ${ }^{33}$ But Rush was not converted to thermometry. He recorded no body temperature ever in the sequence of yellow fever outbreaks he chronicled. And advocacy of cold water in fever does not seem to have at all abated Rush's well-known enthusiasm for bloodletting in fever; he even believed that it would be better to open an artery than a vein if it could be done with ease and safety, especially in children, where a vein might be hard to find. However, some enthusiasm for cold bathing persisted in America for a while; in

\footnotetext{
${ }^{59} \mathrm{~J}$ Worth Estes, 'Naval medicine in the age of sail: the voyage of the New York, 1802-3', Bull. Hist. Med., 1982, 56: 238-53.

${ }^{60}$ Josiah C Trent, 'Benjamin Rush in Edinburgh, 1766-68', in E Ashworth Underwood (ed.), Science, medicine and history: essays ... in honour of Charles Singer, 2 vols, London, Oxford University Press, 1953, vol. 2, pp. 179-85.

${ }^{61}$ Quoted by Martin S Pernick, 'Politics, parties and pestilence: epidemic yellow fever in Philadelphia and the rise of the first party system', in J Worth Estes and Billy G Smith (eds), A melancholy scene of devastation: the
}

public response to the 1793 Philadelphia yellow fever epidemic, Canton, Mass., Science History Publications, 1997, pp. 119-46, on p. 136.

${ }^{62}$ Benjamin Rush, Medical inquiries and observations, to which is added an appendix containing observations on the duties of a physician, and the methods of improving medicine, 2nd ed., 4 vols, Philadelphia, J Conrad [etc.], 1805 , vol. 1, p. 27 , and vol. 3, pp. 295-6. The description of use by American Indians recalls Vespucci's tale; see note 39 above.

${ }^{63}$ Ibid., vol. 4, pp. 47-8. 


\section{James Currie's Cold Water Treatment for Fever}

1802 an allegedly successful trial of Currie's method was carried out in Norfolk, Virginia. ${ }^{64}$

\section{The Abandonment of Cold Water Treatment}

In the end, cold water treatment failed to win a permanent place in the physician's armamentarium against fever. Several reasons can be proposed for this. Currie's son wrote perceptively in 1831 :

Since that time, [i.e. the time of the 4th ed. of Medical reports, just before Currie died] however, it seems that the cold affusion has been less employed in private than Dr Currie was justified in expecting - either succeeded by new modes of combating fever, or owing to its having been occasionally attended by unfavourable results, from injudicious application, or from culpable inattention to his rules. Simple, too, as this practice is in itself, it requires a degree of personal attention and patient discrimination on the part of the medical attendant, which practitioners unfortunately are not always willing, and perhaps not always, from being called in too late, able, to bestow. ${ }^{65}$

One reason for the treatment's abandonment was use in inappropriate circumstances. From the beginning, Currie set out the recommended circumstances in which to use the treatment. Like everyone until long afterwards, he was quite unaware that the physiological mechanisms during the onset of a fever are directed towards establishing a raised body temperature, by shivering and generally increased metabolism, and then (especially if the fever is a cyclic one like typhus, malaria and other tropical fevers) a phase follows where a lower temperature is produced by sweating and similar activities. ${ }^{66}$ But he discerned that the appropriate time for cold water treatment is at the outset of this second phase, when (so to speak) the patient is about to aim at a lower temperature, but has not yet quite started to do so. Currie repeatedly stressed the dry non-sweating skin, hot to the touch, the absence of any chilly feeling, and the raised temperature at this point. Indeed, so far was he from idolatry of the thermometer that he was prepared to overlook temperature readings if the other indications did not concur. He was keenly aware of the danger of using cold water when the patient actually felt cold. Cold water was a procedure to be adopted when the signs were appropriate, and to be repeated if they recurred, but not to be pressed slavishly until the offending temperature responded sufficiently.

Of those who followed him, some erred, like Rush in his first phase, using cold water as a ritual to be followed whenever a fever came to notice. This was a course bound to lead to disaster when a patient instinctively sought heavy bedclothes in

\footnotetext{
${ }^{64} \mathrm{C}$ B Cosby, 'James Currie and

Hydrotherapy', J. Hist. Med. Allied Sci., 1950, 5: 280-8, p. 287.

${ }^{65}$ W W Currie, op. cit., note 16 above, vol. 1 , p. 222.

${ }^{66}$ The progress of discovery is traced by Jan R McTavish, ('Antipyretic treatment and typhoid fever: 1860-1900', J. Hist. Med. Allied
}

Sci., 1982, 42: 486-506), who assigns the date 1875 to the first description of a raised "set point" for temperature in fever. But McTavish is wrong to write (p. 490) that "Currie offered no real guidance for the application of his treatment." The guidance is quoted in the present paper. 


\section{John M Forrester}

order to reach a higher temperature, but was plunged instead into cold water to make the task much harder-or else, being already weak and cool after an access of fever, was made to strive to regain a normal temperature in a cold bath.

A second reason for the abandonment of the treatment was its unfamiliar and exacting nature, so that physicians hesitated to give adequate treatment. It is plain from, for instance, the third Hufeland prize essay, that whatever might be done in the Navy or in hospitals, in the home, especially, the heroic aspects of cold water treatment were rarely appreciated by the patients and their families, who were well content with cold water washing or simply wet cloths round the head. ${ }^{67} \mathrm{~A}$ range of other treatments for fever was always available, and they were not mutually exclusive. ${ }^{68}$

A third probable reason for its abandonment was diagnostic confusion. The treatment was launched particularly through its successful use in tropical transmissible fevers such as malaria and in scarlet fever. Its success there led to its use in a wide and heterogeneous range of "fevers" not necessarily accompanied by raised body temperature, a process the more easy since so few of its exponents used thermometers at all. Currie himself, proficient at thermometry, never insisted on a raised body temperature before starting cold water treatment. Thus, like others, he applied it to "convulsive disorders" and "violent insanity" and tetanus, in none of which did he record body temperatures, although the water temperature might be recorded ${ }^{69}$ In Germany even scalds and burns, dysentery and sprains might be seen as occasions of "fever" and eligible for treatment à la Currie. ${ }^{70}$ As a cure-all of this kind it could hardly command lasting success.

A better understanding of the function of perspiration had opened wide the door to cold water therapy for fever, but could not close the door against the longestestablished treatment: bloodletting. Even to Currie bloodletting and cold water were

\footnotetext{
${ }^{67}$ Jackson, op. cit., note 41 above, p. 4: the benefits of cold water treatment "have been proved incontestibly [sic] on the bodies of British soldiers and British sailors, and on the subjects of hospitals and dispensaries; but it is little known in this country beyond that circle. It is thus as yet a remedy of the vulgar." A graffito in the Edinburgh University copy of the $1805 \mathrm{ed}$. of Currie's Medical reports (note 32 above) remarks that "patients during the application of this remedy require nearly as much encouragement as women in Labour"!

${ }^{68} \mathrm{See}$, for instance, Estes, op. cit., note 59 above.

${ }^{69}$ For tetanus see op. cit., note 28 above, Appendix 1. A sensational case of "tetanus" reported by Currie can now be interpreted; the condition came on in a soldier after two days of heavy drinking and dancing, but without other evident reason, and the soldier was thrown
}

\begin{abstract}
"headlong" into the public bath as therapy; two hours later he was conscious, and made a rapid and complete recovery. Doubtless he had hyperventilation tetany through excitement, not tetanus. A similar "tetanus" appearing during strong emotion and vanishing after just two episodes is recorded in an Edinburgh ward ledger dated 1773 (Lothian Health Board Archive $1 / 125 / 2$, pp. $401 \mathrm{ff}$.). The rationale for the grouping of tetanus and convulsive disorders with fevers in the nosology of the time is that in both the pulse is fast, and there may be sweating (see, for example, George Fordyce, Third dissertation on fever, containing the history and method of treatment of a regular continued fever, supposing it is left to pursue its ordinary course, London, for $\mathrm{J}$ Johnson, 1798, pt I, p. 7).

${ }^{70} \mathrm{~J} \mathbf{J}$ Reuss in op. cit., note 54 above, pt 2 , sect. 1 .
\end{abstract}


not alternatives, but might be employed together in fever. ${ }^{71}$ Just as he had demonstrated that cold bathing immediately reduced body temperature, so he believed that he had demonstrated the same thing for bloodletting. ${ }^{72}$

He was his own experimental subject: being subject to fevers throughout his life, he noted in himself that when his temperature was $103^{\circ} \mathrm{F}$ as recorded by thermometer held in his hand and he was bled, the reading fell within seconds and soon reached $91^{\circ}$, at which point he fainted, and the reading taken by his assistant was $83^{\circ}$ before the bloodletting was brought to a close.$^{73}$ It is not evident why Currie did not adhere to his own advice already quoted, to place the thermometer bulb under his tongue, or in his axilla, where the reading would have been virtually unaffected by the constriction of peripheral circulation which occurs in stress and fainting during bloodletting. ${ }^{74}$ If he had done so, he would have found that bloodletting left the central body temperature unchanged; the hand temperature falls because so little blood is reaching it. ${ }^{75}$ But he would not have been able to take the reading himself if the thermometer had been in either of these sites.

Earlier enquirers had recorded temperatures on subjects presumably adequately warm, and had noted that in general a thermometer held in the hand gave the same reading as one in the mouth. Sanctorius recorded hand as well as mouth temperatures, but he was not comparing their settled values; he was recording their rates of change. ${ }^{76}$ Martine knew that while he lay in a warm bed the reading was the same in the hand, between the thighs, in the axilla or in the mouth, and in the urine voided into a pre-warmed pot; ${ }^{77}$ and van Swieten believed that at least in fever either mouth or hand would do; though he thought that deeper parts even less exposed to the air than mouth or hand would be hotter, he does not say how this could be established. ${ }^{78}$ Obviously when readings take long to make, two instruments and patience are required to demonstrate a difference between hand and mouth. So probably few looked for one before Currie, though Anton de Haen did once, when a patient's arm probably had a very poor circulation; the hand temperature was only $73^{\circ} \mathrm{F}$ but the axillary temperature was $96^{\circ} .{ }^{79}$ And no doubt Robert Boyle was recording the same phenomenon indirectly long before, when he noted that the

\footnotetext{
${ }^{71}$ But he used bloodletting rarely in "contagious fever" (op. cit., note 32 above, p. 245.) Cosby, however, is wrong to state that "Currie to the end fought bloodletting as unnecessarily debilitating regardless of the refrigeration it caused" (op. cit., note 64 above, p. 287). If this were true, Currie might have lived longer, as explained later in the present paper.

${ }^{72}$ There was theory to explain this: if, as Boerhaave and Stahl held, the major source of body heat is friction within the circulation, then venesection is to be recommended frequently in fever, since the mass of moving liquid is reduced; the densest part of our liquids, suited to taking up and retaining heat, is removed; and room is made for liquid to dilute the over-thickened blood. This is the argument of van Swieten (op. cit., note 26 above, vol. 2 , sect. 691, p. 306).
}

\footnotetext{
${ }^{73}$ James Currie, op. cit., note 32 above, vol. 2, p. 245; this material is not in the earlier 1798 edition.

${ }^{74}$ James Currie, op. cit., note 28 above, p. 33.

${ }^{75}$ Risse (op. cit., note 29 above, p. 203) asserts that body temperature did decline on removal of 4-8 ounces of blood, but provides no evidence, and there is no reason to expect such a change.

${ }^{76}$ Knowles Middleton, op. cit., note 23 above, p. 13.

${ }^{77}$ Martine, op. cit., note 8 above, p. 173.

${ }^{78}$ Van Swieten, op. cit., note 26 above, vol. 2 (1749), sect. 673, p. 287. 25.

${ }^{79}$ De Haen, op. cit., note 33 above, vol. 1, ch.
} 


\section{John M Forrester}

temperature of the shed blood of a "young gentlewoman" was much lower than that of a middle-aged man, who was probably less susceptible to the stress of being bled. $^{80}$

His unhappy misinterpretation of the normal phenomena of vasoconstriction during haemorrhage caused Currie, no doubt, to bleed many patients without good cause, and also himself, for he insisted that his physicians should bleed him far more than they thought wise. ${ }^{81}$ How much more sensible the homely advice of George Stephenson (1781-1848) of railway engine fame, to a friend who had come to London to be bled: "Nonsense, Tom; go away home; draw your fires, don't blow off steam." 82 If the trial proposed by George Fordyce (1798) had been carried out, Currie might have lived longer: "Practitioners also have not compared cases of fevers in which it [bloodletting] has been practised, and of fever treated otherwise in the same manner in which it has not been practised. ${ }^{~} 83$ But Edinburgh was still arguing violently about the merits of bloodletting in the 1850 s, so it continued in active use half a century after Currie's death. ${ }^{84}$

For fever, bloodletting is now more deeply buried in the past than cold-water treatment, which enjoyed a resurgence for typhoid fever with the work (1861) of Dr Brand of Stettin, and was still within living memory in 1964, but is now forgotten, unless as a counsel of desperation where the body temperature has reached extreme levels. ${ }^{85}$

\footnotetext{
${ }^{80}$ See Everett Mendelsohn, Heat and life: the development of the theory of animal heat, Cambridge, Mass., Harvard University Press, 1964, p. 66.

${ }^{81}$ See, for example, W W Currie, op. cit., note 16 above, vol. 1, pp. 83, 344, 353, 364.

${ }^{82}$ Quoted by Archibald Hunter, Hydropathy, its principles and practice for home use, Edinburgh and Glasgow, John Menzies, 1878, p. viii.

${ }^{83}$ Op. cit., note 69 above, Part II, pp. 6ff.

${ }^{84}$ See John Harley Warner, 'Therapeutic explanation and the Edinburgh bloodletting controversy: two perspectives on the medical meaning of science in the mid-nineteenth century', Med. Hist., 1980, 24: 241-58; and Lester $\mathrm{S}$ King, 'The blood-letting controversy: a study in the scientific method', Bull. Hist. Med., 1961, 35: $1-13$.

${ }^{85}$ E N Chamberlain, 'James Currie-his life and times', Proc. Roy. Soc. Med., 1964, 57:
}

$907-10$, p. 909 . The whole story is discussed in McTavish, op. cit., note 66 above. Vigorously chilling a feverish patient is now discouraged, for two reasons. First, a violent and exhausting response of shivering and so forth is evoked. And second, the fever may itself be in a general way beneficial. Non-mammalian animals which are infected and would naturally seek a warmer environment can be prevented from doing so, without provoking the exhausting response typical of mammals, which maintain a specific body temperature. It then appears that, nevertheless, the animals survive less successfully than others allowed to reach a warmer environment. See B Cox, P Lomax, et al. (eds), Thermoregulatory mechanisms and their therapeutic implications, Basel, Karger, 1980; and, especially for a full account, Matthew J Kluger, Fever: its biology, evolution, and function, Princeton University Press, 1979. 